CARRA Working Paper Series

Working Paper Series \#2014 - 16

Exploring Administrative Records Use for Race and Hispanic Origin Item Non-Response

\author{
Sonya Rastogi \\ U.S. Census Bureau \\ Leticia Fernandez \\ U.S. Census Bureau \\ James Noon \\ U.S. Census Bureau \\ Ellen Zapata \\ U.S. Census Bureau \\ Renuka Bhaskar \\ U.S. Census Bureau
}

Center for Administrative Records Research and Applications

U.S. Census Bureau

Washington, D.C. 20233

Paper Issued: 12/23/2014

Disclaimer: This paper is released to inform interested parties of research and to encourage discussion. The views expressed are those of the authors and not necessarily those of the U.S. Census Bureau. 


\title{
Exploring Administrative Records Use for Race and Hispanic Origin Item Non-Response ${ }^{1}$
}

\author{
Sonya Rastogi, U.S. Census Bureau \\ Leticia Fernandez, U.S. Census Bureau \\ James Noon, U.S. Census Bureau \\ Ellen Zapata, U.S. Census Bureau \\ Renuka Bhaskar, U.S. Census Bureau
}

\begin{abstract}
Race and Hispanic origin data are required to produce official statistics in the United States. Data collected through the American Community Survey and decennial census address missing data through traditional imputation methods, often relying on information from neighbors. These methods work well if neighbors share similar characteristics, however, the shape and patterns of neighborhoods in the United States are changing. Administrative records may provide more accurate data compared to traditional imputation methods for missing race and Hispanic origin responses. This paper first describes the characteristics of persons with missing demographic data, then assesses the coverage of administrative records data for respondents who do not answer race and Hispanic origin questions in Census data. The paper also discusses the distributional impact of using administrative records race and Hispanic origin data to complete missing responses in a decennial census or survey context.
\end{abstract}

\footnotetext{
${ }^{1}$ A version of this paper was presented at the United Nations Economic Commission for Europe Conference of European Statisticians in April 2014 and is available as a United Nations working paper at:

http://www.unece.org/fileadmin/DAM/stats/documents/ece/ces/ge.44/2014/mtg1/Topic_4_USA_Rastogi_rev1.pdf
} 


\section{Introduction}

Race and Hispanic origin data from the Census Bureau are critical to evaluating and supporting the enforcement of civil rights laws such as the Voting Rights Act, Civil Rights Act, and Fair Housing Act. These data are also used in congressional redistricting. Policy makers and academic researchers rely on these data to document and study a broad range of issues, such as the association between race and socioeconomic disparities.

A small proportion of people in the decennial census and census surveys, however, do not provide an answer to questions on race and Hispanic origin. To address item nonresponse and its potential consequences on population estimates, several procedures have been developed and are used by the US Census Bureau. One of these procedures is the utilization of hot decks, where data from a nearest neighbor or unit with similar characteristics are used to impute missing data. While hot decks are widely used in surveys, as the diversity of the United States increases and the shape and patterns of neighborhoods change, administrative records, when available, may provide more accurate data compared to traditional imputation methods. Record linkage techniques allowed the Census Bureau to utilize previous responses from Census 2000 and survey data to assign race and Hispanic origin responses to observations with missing data in the 2010 Census. This reduced the percentage of records that required hot deck imputation by 50 percent for race and 60 percent for Hispanic origin in the 2010 Census.

This paper explores the feasibility of utilizing administrative records to further minimize the imputation universes arising from race and Hispanic origin nonresponse. We first describe the agreement between administrative records race and Hispanic origin data compared to householdreported unedited 2010 Census responses. Next, we describe the coverage administrative records provide to the race and Hispanic origin imputation universes and discuss their race and Hispanic origin agreement rates.

Finally, utilizing logistic regression techniques, we assess the characteristics of individuals whose race or Hispanic origin were imputed in the 2010 Census, as well as the characteristics of those whose had imputed race or Hispanic origin and also had a corresponding race or Hispanic origin response in administrative records.

This study contributes to the growing research on the potential uses of administrative records to reduce survey collection costs while at the same time improving the quality of imputations. We aim to increase understanding of the coverage and accuracy of administrative records for race and Hispanic origin items compared to hot deck imputation procedures.

\section{Literature/Background}

Early research at the Census Bureau on administrative records race and Hispanic origin data utilized primarily one source, the Numerical Identification System (Numident) which includes everyone in the United States that has been issued a Social Security Number. Farber and Leggieri (2002) reported that the Numident had a lower representation of racial and ethnic minorities relative to Census 2000. They attributed this to primarily three issues. First, the Numident combines race and Hispanic origin into one concept, whereas the Census 2000 had separate questions on race and Hispanic origin. Second, the Numident does not account for 
multiple race responses, while multiple race responses were permitted in Census 2000. Finally, as a result of a change in data collection procedures at the Social Security Administration (SSA), after the late 1980s SSA collected race and Hispanic origin data for only a limited number of people. Farber and Leggieri (2002) imputed race and Hispanic origin to observations in the Numident with missing data. Given that younger age groups, for whom the Numident is missing race and Hispanic origin data, are more diverse than older age groups, their imputation likely underestimates minority groups.

Building on this research, more recent analyses compared the 2010 Census race and Hispanic origin responses to various federal and commercial administrative sources and found that agreement of race and Hispanic origin responses varied considerably across racial groups (Rastogi and O’Hara 2012). White alone and Black alone populations tended to have high agreement rates. The Asian alone population had moderate agreement rates. The American Indian or Alaska Native (AIAN) alone, Native Hawaiian or Other Pacific Islander (NHPI) alone, and Two or More Races populations had low agreement rates. Agreement between NonHispanic responses in the 2010 Census and administrative records was high, while agreement for Hispanics was moderate. Similar results were found when administrative records sources were compared to the 2010 American Community Survey (Bhaskar et al. 2014).

Research has also been conducted to evaluate the use of administrative records for race and Hispanic origin item imputation. Farber et al. (2005), using a truth deck ${ }^{2}$ from Census 2000 data, found that administrative records matched 96 percent of the race responses and 98 percent of the Hispanic origin responses in the Census sample (Farber et al. 2005). Focusing on four states, Delaware, Georgia, New York and Florida, Obenski et al. (2005) refined this analysis by comparing hot deck and administrative records race and Hispanic origin responses to a Census 2000 truth deck. They found that administrative records had considerably higher levels of consistency with Census race responses, at 96.5 percent compared to 75.7 percent for the hot deck procedure. Administrative records also had a higher consistency (99 percent) relative to hot deck (95.4 percent) for Hispanic origin, although matching rates were closer compared to race data. The authors recommended a hybrid approach to item imputation for race and Hispanic origin, using administrative records when available and then hot deck for the remainder of missing values.

In the next sections we show the coverage that administrative records provide for race and Hispanic origin item imputation. We also examine the characteristics associated with individuals who receive imputed race and Hispanic origin data, as well as the characteristics of the subpopulation of these individuals who have imputed values and also are covered by administrative records. The last part of the analysis estimates the odds of administrative record coverage by individual-level, household, and geographic characteristics.

\footnotetext{
${ }^{2}$ The truth deck was derived from Census 2000 responses in which some data are deliberately blanked to represent Census 2000 nonresponse patterns.
} 


\section{Data and Methods}

For this analysis we use the 2010 decennial census and administrative records data from several federal and commercial sources. The federal administrative records included in this study are from the Department of Housing and Urban Development rental assistance, housing assistance and Federal Housing Authority loan application records, the Indian Health Service Patient Registration System, Medicaid, Medicare Enrollment Database, Supplemental Nutrition Assistance Program (SNAP) data from Texas, Temporary Assistance for Needy Families, and the Numident. Data from five commercial vendors are also used (see Rastogi and O’Hara 2012 for more information on data).

The Hispanic origin variable in administrative records was created by combining all ethnicity data from the administrative sources listed above. The race variable in administrative records was drawn from all of the files above, except Medicaid, SNAP Texas, and the commercial files.

This paper provides descriptive results and utilizes logistic regressions to model the factors associated with both the need for hot deck imputation and having a response in administrative records. In the first part of our analysis, we compare in separate models for race and Hispanic origin, the characteristics of individuals who have their responses imputed by hot deck (coded as 1) versus those who were self-reported or had another type of edit or imputation (coded as 0 ). The second set of regressions also model race and Hispanic origin separately. These models examine the factors associated with having a response in administrative records for individuals who in the 2010 Census received a hot deck imputation (coded as 1) versus individuals who have 2010 Census hot deck imputations but are not in administrative records.

We utilize the limited number of independent variables that are available from the decennial census: Hispanic origin, race, age groups, gender, household composition, household size, mode of response, region, and rural or urban area. Median income in the tract of residence is derived from the American Community Survey data.

\section{Findings}

\section{A. Race and Hispanic Origin Responses in Administrative Records Compared to 2010 Census As Reported No Proxy Responses}

To provide context for the consistency of race and Hispanic origin responses between administrative records and 2010 Census hot deck-imputations, we first discuss the level of agreement between 2010 Census as reported, no proxy responses and administrative records. ${ }^{3}$ Table 1 shows the high levels of consistency between the 2010 Census and administrative records used in this study, with 97 percent of non-Hispanics and 94 percent of Hispanics having the same response in both data sources.

\footnotetext{
${ }^{3}$ As reported, no proxy data is defined as unimputed and unedited data that was provided by a household member, rather than a proxy such as a neighbor or building manager.
} 
In terms of race responses, Table 2 shows that administrative records race responses have high match rates for the White alone (96 percent), Black alone (96 percent), and Asian alone (91 percent) populations. The match rate for the AIAN alone (74 percent) population is moderate, followed by NHPI alone (57 percent) and Some Other Race (SOR) alone (49 percent). The lowest match rate is for the multiple race population, with only 29 percent of the individuals reporting multiple races in both data sources. One possible explanation for these differences is racial fluidity, the propensity of some individuals to report a different race over time or when contexts change. Racial fluidity may impact all race and Hispanic origin groups to some extent, but we may observe this to a greater extent for the NHPI, AIAN, and multiple race populations (Doyle and Kao 2007, Harris and Sim 2002, Kana 'iaupuni and Liebler 2005, Khanna 2012, Liebler et al. 2014). Both NHPI and AIAN populations have large proportions of individuals that identify with their mixed heritage. A second issue is that some of the sources that are used in the administrative records race dataset do not allow for multiple race reporting, so these differences may be attributed to forcing multiple race individuals to choose a single race from their mixed heritage.

\section{B. Adminis trative Records Coverage of the 2010 Census Imputation Universe}

Administrative records only cover about 13 percent of hot deck-imputed race responses in the 2010 Census. For Hispanic origin, three different hot deck procedures are used, one with Spanish surnames, one with non-Spanish surnames, and one with no surnames. Administrative records cover 42 percent of non-Spanish surname hot deck-imputed responses, and 18 percent and 20 percent, respectively, of no surname and Spanish surname hot deck responses. While not the focus of this paper, other race and Hispanic origin edits and imputation procedures have higher coverage rates. Future research should consider how administrative records could assist with these edits and imputations.

\section{Match of Hot Deck Imputations Compared to Adminis trative Records}

Tables 3 and 4 show 2010 Census hot deck-imputed Hispanic origin and race, respectively, compared to the data in administrative records. As shown in Table 3, a high percentage of 2010 Census non-Hispanic hot deck-imputed responses match to administrative records non-Hispanic responses (96 percent). There is considerably lower agreement for Hispanics (54 percent). Given the high consistency in Hispanic origin responses found between administrative records and the 2010 Census as reported, no proxy data, administrative records should be used for missing Hispanic origin responses when available. Some respondents with missing data are not in administrative records, thus hot deck imputation methods will still need to be utilized.

Table 4 shows that when the hot deck imputes White alone, the match rate with administrative records is relatively high (83 percent), but about 8 percent and 6 percent of those imputed as White alone via hot deck are SOR alone and Black alone, respectively, in administrative records. The match between imputed responses and administrative records for Black alone is considerably lower than for White alone, where 52 percent indicate Black alone in both data sources. Administrative records indicate that 42 percent of those imputed by the hot deck procedure as Black alone have reported as White alone in administrative records. The match rates for all other groups are extremely low, ranging from 1 percent for the multiple race population to 17 percent for the SOR alone population. When administrative records race is 
matched to 2010 Census as reported, no proxy responses, all of the match rates are higher than the match rates for the imputed universe, suggesting that administrative records would provide more accurate responses for race groups relative to the hot deck imputation procedure; however, the level of accuracy would still vary by race group.

\section{Characteris tics Associated with Hot Deck Imputation Due to Non-Response}

\section{Race Imputations}

Model 1 of Table 5 shows the factors associated with race imputations. Hispanics of any race are eight times more likely to have their race imputed than non-Hispanic White alone individuals. This is not surprising, as many Hispanics see their race as Hispanic and therefore choose not to answer the race question when presented with separate questions on Hispanic origin and race (Campbell and Rogalin 2006, Compton et al. 2012). Non-Hispanic Black and multiple races are less likely to be imputed relative to non-Hispanic White. In contrast, non-Hispanic NHPI, and to a lesser extent non-Hispanic Asian, are more likely to be imputed. The odds of imputing nonHispanic AIAN and non-Hispanic SOR are similar to those of non-Hispanic White alone.

There are also differences in rates of race imputation associated with age, gender and household characteristics. The likelihood of having race imputed declines with age; is lower for females compared to males; and less likely for individuals in large households and those headed by a married couple compared to small households and those headed by single fathers, single mothers or other family types. Not surprisingly, renters and individuals that neither rent nor own are more likely to have race imputed than homeowners; however, the higher the median income in the tract of residence, the higher the odds of race imputations.

Imputation rates are also higher for individuals in rural areas, in the West, and among those in non-response follow up operations relative to urban residents, those living in other areas of the country, and those who respond through mail or other modes of data collection.

\section{Hispanic Origin Imputations}

As Model 2 of Table 5 shows, the odds of having Hispanic origin imputed are lower for Hispanics of any race than for single race non-Hispanic Whites. All non-Hispanic race groups have higher odds of being imputed a Hispanic origin relative to single race non-Hispanic White, and these odds are almost twice as large or larger for single race Black, AIAN, Asian, and NHPI. The likelihood of Hispanic origin imputation increases with age and is slightly higher for males than females. In contrast, imputation is less likely in larger households and those headed by a married couple relative to smaller households and those headed by single parents or other family compositions.

Renters and individuals who neither rent nor own have higher odds of imputation than homeowners. However, contrary to our findings regarding race imputations, the higher the median income in the tract of residence, the lower the odds that an individual will have Hispanic origin imputed. 
Living in rural areas, in the West, and responding to the Census through follow up operations or other non-mail modes are all associated with higher imputation rates than urban living, residence in other regions, and those responding by mail.

\section{E. Characteristics of Individuals with Imputed Responses Who are in Administrative Records}

Race

In Model 3 of Table 5 we show how the variables in the analysis influence the odds of being in the 2010 Census race imputation universe and also administrative records. Except for nonHispanic Black, all other groups including Hispanics of any race, have lower odds of having an administrative records race response in the 2010 Census imputation universe relative to nonHispanic White.

These odds of being in the administrative records/2010 Census imputation universe increase with age, which confirms that administrative records do not cover 0 to 17-year-olds well (Rastogi and O’Hara 2012), and this is likely compounded by the higher likelihood that young individuals will be in the race imputation universe. In addition, the odds are higher for males, for individua ls living alone, and for those in households headed by single mothers compared to females, those in larger households, and those living in households with married couples or other family compositions.

In contrast, renters and individuals who neither rent nor own are less likely to be in this universe compared to owners; and these odds also decline with higher median income in the tract of residence.

Residence in rural areas, and those living in the Midwest and Southern regions of the country are associated with lower odds compared to urban areas and living in the West, but the odds of being in the administrative records/2010 Census race imputation universe are higher for those living in the Northeast region. Relative to mail, those who responded in non-response follow-up or other modes have much lower odds of being in the administrative records/2010 Census universe.

\section{Hispanic Origin}

Model 4 of Table 5 shows that compared to single race non-Hispanic Whites, all race and ethnic groups have higher odds of being in the administrative records/2010 Census Hispanic imputation universe. Similarly, individuals in age groups 18 and older have higher odds than younger individuals. Males have slightly lower odds compared to females.

The patterns we observe in the race model for household composition, home ownership, household income in the tract of residence, mode of data collection and rural/urban residence are similar in the Hispanic origin model, and larger households are also less likely to be in the administrative records/2010 Census Hispanic imputation universe than single-person households. However, region of residence shows a different pattern. Persons living in the Midwest, South or 
Northeast have higher odds of being in administrative records and the 2010 Census Hispanic origin imputation universe compared to those in the West.

\section{Conclusion}

Our findings suggest that administrative records are a promising avenue to complement and improve the quality of imputations for missing race and Hispanic origin data. Administrative records do not cover all individuals with missing race and Hispanic origin responses, and their coverage varies across race, Hispanic origin, and other individual and geographic characteristics. Thus, hot deck and other methods will remain important for addressing race and Hispanic origin missing data. Understanding the characteristics of individuals with imputed race and Hispanic origin, as well as the variables associated with their inclusion in administrative records, may enhance strategies to address non-response and the quality of imputed data. 


\section{References}

Bhaskar, Renuka, Adela Luque, Sonya Rastogi, and James Noon. 2014. "Coverage and Agreement of Administrative Records and 2010 American Community Survey Demographic Data.” Center for Administrative Records Research and Application Working Paper \#2014-14.

Campbell, Mary E. and Christabel L. Rogalin. 2006. Categorical Imperatives: The Interaction of Latino and Racial Identification. Social Science Quarterly, 87(5): 1030-1052.

Compton, Elizabeth, Michael Bentley, Sonya Rastogi and Sharon Ennis. 2012. 2010 Census Race and Hispanic Origin Alternative Questionnaire Experiment. DSSD 2010 CPEX Memorandum Series \#B-05-R, 2010 Census Planning Memoranda Series \#211, U.S. Census Bureau.

Doyle, Jamie M. and Grace Kao. 2007. Are Racial Identities of Multiracials Stable? Changing Self-Identification among Single and Multiple Race Individuals. Social Psychology Quarterly, 70(4): 405-423.

Farber, James, and Charlene Leggieri. 2002. "Building and Validating a National Administrative Records Database for the United States.” New Zealand Conference on Database Integration.

Farber, James, Deborah Wagner, and Dean Resnick. 2005. "Using Administrative Records for Imputation in the Decennial Census.” Survey Research Methods Section Proceedings of the Joint Statistical Meetings.

Harris, David .R. and Jeremiah J. Sim. 2002. Who is Multiracial? Assessing the Complexity of Lived Race. American Sociological Review, 67(4): 614-627.

Kana'iaupuni, Shawn M. and Carolyn A. Liebler. 2005. Pondering Poi Dog: Place and Racial Identification of Multiracial Native Hawaiians. Ethnic and Racial Studies, 28(4): 687-721.

Khanna, Nikki. 2012. Multiracial Americans: Racial Identity Choices and Implications for the Collection of Race Data. Sociology Compass, 6/4: 316-331.

Liebler, Carolyn, Sonya Rastogi, Leticia E. Fernandez, James M. Noon, and Sharon R. Ennis. 2014. “America's Churning Races: Race and Ethnic Response Changes between Census 2000 and the 2010 Census.” Center for Administrative Records Research and Applications Working Paper \#2014-09.

Obenski, Sally, James Farber, and Gary Chappell. 2005. "Research to Improve Census Imputation Methods: Item Results and Conclusions.” Survey Research Methods Section Proceedings of the Joint Statistical Meetings.

Rastogi, Sonya, and Amy O’Hara. 2012. “2010 Census Match Study.” 2010 Census Evaluations, Experiments, and Assessments Report. 
Table 1.2010 Census As Reported, No Proxy Hispanic Origin Responses Compared to Administrative Records Hispanic Origin Reponses

\begin{tabular}{|l|r|r|r|}
\hline \multirow{2}{*}{$\begin{array}{c}\text { Census Hispanic Origin, As } \\
\text { Reported No Proxy }\end{array}$} & \multicolumn{3}{|c|}{ Administrative Records Hispanic Origin } \\
\cline { 2 - 4 } & Non-Hispanic & \multicolumn{1}{c|}{ Hispanic } & \multicolumn{1}{c|}{ Total } \\
\hline $\begin{array}{l}\text { Non-Hispanic } \\
\text { Number }\end{array}$ & $\mathbf{1 9 1 , 3 1 8 , 6 4 4}$ & $6,374,500$ & $197,693,144$ \\
Percent & $\mathbf{9 6 . 8}$ & 3.2 & 85.6 \\
\hline $\begin{array}{l}\text { Hispanic } \\
\text { Number }\end{array}$ & $2,100,834$ & $\mathbf{3 1 , 0 2 5 , 2 3 6}$ & $33,126,070$ \\
Percent & 6.3 & $\mathbf{9 3 . 7}$ & 14.4 \\
\hline Total & $193,419,478$ & $37,399,736$ & $\mathbf{2 3 0 , 8 1 9 , 2 1 4}$ \\
& 83.8 & 16.2 & $\mathbf{1 0 0 . 0}$ \\
\hline
\end{tabular}

Source: 2010 Census and Administrative Records. 
Table 2.2010 Census As Reported, No Proxy Race Compared to Administrative Records Race

\begin{tabular}{|c|c|c|c|c|c|c|c|c|}
\hline & & & Adn & inistrative & Records I & ace & & \\
\hline $\begin{array}{c}\text { Census Race, } \\
\text { As Reported } \\
\text { No Proxy } \\
\end{array}$ & $\begin{array}{l}\text { White } \\
\text { Alone }\end{array}$ & $\begin{array}{l}\text { Black } \\
\text { Alone }\end{array}$ & $\begin{array}{l}\text { AIAN } \\
\text { Alone* }\end{array}$ & $\begin{array}{l}\text { Asian } \\
\text { Alone }\end{array}$ & $\begin{array}{c}\text { NHPI } \\
\text { Alone* }\end{array}$ & $\begin{array}{c}\text { SOR } \\
\text { Alone* }\end{array}$ & $\begin{array}{l}\text { Two or } \\
\text { More } \\
\text { races } \\
\end{array}$ & Total \\
\hline $\begin{array}{l}\text { White Alone } \\
\text { Number } \\
\text { Percent }\end{array}$ & $\begin{array}{r}160,526,904 \\
96.4\end{array}$ & $\begin{array}{r}368,564 \\
0.2\end{array}$ & $\begin{array}{r}577,544 \\
0.4\end{array}$ & $\begin{array}{r}112,955 \\
0.1\end{array}$ & $\begin{array}{r}57,039 \\
0.0\end{array}$ & $\begin{array}{r}3,352,489 \\
2.0\end{array}$ & $\begin{array}{r}1,493,245 \\
0.9\end{array}$ & $\begin{array}{r}166,488,740 \\
77.8\end{array}$ \\
\hline $\begin{array}{l}\text { Black Alone } \\
\text { Number } \\
\text { Percent } \\
\end{array}$ & $\begin{array}{r}239,345 \\
0.9 \\
\end{array}$ & $\begin{array}{r}26,354,105 \\
96.4 \\
\end{array}$ & $\begin{array}{r}81,910 \\
0.3 \\
\end{array}$ & $\begin{array}{r}24,381 \\
0.1 \\
\end{array}$ & $\begin{array}{r}6,900 \\
0.0 \\
\end{array}$ & $\begin{array}{r}208,767 \\
0.8 \\
\end{array}$ & $\begin{array}{r}433,701 \\
1.6 \\
\end{array}$ & $\begin{array}{r}27,349,109 \\
12.8 \\
\end{array}$ \\
\hline $\begin{array}{l}\text { AIAN Alone* } \\
\text { Number } \\
\text { Percent } \\
\end{array}$ & $\begin{array}{r}299,574 \\
14.9 \\
\end{array}$ & $\begin{array}{r}54,299 \\
2.7 \\
\end{array}$ & $\begin{array}{r}1,483,283 \\
73.9 \\
\end{array}$ & $\begin{array}{r}5,140 \\
0.3 \\
\end{array}$ & $\begin{array}{r}1,635 \\
0.1 \\
\end{array}$ & $\begin{array}{r}89,208 \\
4.4 \\
\end{array}$ & $\begin{array}{r}74,457 \\
3.7 \\
\end{array}$ & $\begin{array}{r}2,007,596 \\
0.9 \\
\end{array}$ \\
\hline $\begin{array}{l}\text { Asian Alone } \\
\text { Number } \\
\text { Percent } \\
\end{array}$ & $\begin{array}{r}125,542 \\
1.7 \\
\end{array}$ & $\begin{array}{r}20,729 \\
0.3 \\
\end{array}$ & $\begin{array}{r}39,875 \\
0.5 \\
\end{array}$ & $\begin{array}{r}6,794,143 \\
91.1 \\
\end{array}$ & $\begin{array}{r}23,663 \\
0.3 \\
\end{array}$ & $\begin{array}{r}186,865 \\
2.5 \\
\end{array}$ & $\begin{array}{r}269,248 \\
3.6 \\
\end{array}$ & $\begin{array}{r}7,460,065 \\
3.5 \\
\end{array}$ \\
\hline $\begin{array}{l}\text { NHPI Alone* } \\
\text { Number } \\
\text { Percent }\end{array}$ & $\begin{array}{r}25,890 \\
10.2\end{array}$ & $\begin{array}{r}4,145 \\
1.6\end{array}$ & $\begin{array}{r}1,843 \\
0.7\end{array}$ & $\begin{array}{r}13,565 \\
5.3\end{array}$ & $\begin{array}{r}145,945 \\
57.3\end{array}$ & $\begin{array}{r}13,743 \\
5.4\end{array}$ & $\begin{array}{r}49,561 \\
19.5 \\
\end{array}$ & $\begin{array}{r}254,692 \\
0.1\end{array}$ \\
\hline $\begin{array}{l}\text { SOR Alone* } \\
\text { Number } \\
\text { Percent } \\
\end{array}$ & $\begin{array}{r}2,223,584 \\
40.3 \\
\end{array}$ & $\begin{array}{r}154,204 \\
2.8 \\
\end{array}$ & $\begin{array}{r}87,549 \\
1.6 \\
\end{array}$ & $\begin{array}{r}30,372 \\
0.6 \\
\end{array}$ & $\begin{array}{r}11,356 \\
0.2 \\
\end{array}$ & $\begin{array}{r}2,724,766 \\
49.4 \\
\end{array}$ & $\begin{array}{r}280,960 \\
5.1 \\
\end{array}$ & $\begin{array}{r}5,512,791 \\
2.6 \\
\end{array}$ \\
\hline $\begin{array}{l}\text { Two or More } \\
\text { Races } \\
\text { Number } \\
\text { Percent }\end{array}$ & $\begin{array}{r}1,646,971 \\
34.0 \\
\end{array}$ & $\begin{array}{r}705,288 \\
14.6 \\
\end{array}$ & $\begin{array}{r}386,370 \\
8.0 \\
\end{array}$ & $\begin{array}{r}256,765 \\
5.3 \\
\end{array}$ & $\begin{array}{r}65,492 \\
1.4 \\
\end{array}$ & $\begin{array}{r}395,732 \\
8.2 \\
\end{array}$ & $\begin{array}{r}1,381,532 \\
28.6\end{array}$ & $\begin{array}{r}4,838,150 \\
2.3\end{array}$ \\
\hline Total & $\begin{array}{r}165,087,810 \\
77.2 \\
\end{array}$ & $\begin{array}{r}27,661,334 \\
12.9 \\
\end{array}$ & $\begin{array}{r}2,658,374 \\
1.2 \\
\end{array}$ & $\begin{array}{r}7,237,321 \\
3.4 \\
\end{array}$ & $\begin{array}{r}312,030 \\
0.2 \\
\end{array}$ & $\begin{array}{r}6,971,570 \\
3.3 \\
\end{array}$ & $\begin{array}{r}3,982,704 \\
1.9\end{array}$ & $\begin{array}{r}213,911,143 \\
100.0\end{array}$ \\
\hline
\end{tabular}

Source: 2010 Census and Administrative Records.

* AIAN is an acronym for American Indian or Alas ka Native, NHPI is an acronymfor Native Hawaiian or Other Pacific Islander, and SOR is an acronymfor Some Other Race. 
Table 3. Comparis on of 2010 Census Hot Deck Imputed Hispanic Origin Matched to Administrative Records Hispanic Origin

\begin{tabular}{|l|r|r|r|}
\hline Census Hot Deck & \multicolumn{4}{|c|}{ Administrative Records Hispanic Origin } \\
\cline { 2 - 4 } Hispanic Origin & Non-Hispanic & \multicolumn{1}{c|}{ Hispanic } & \multicolumn{1}{l|}{ Total } \\
\hline Non-Hispanic & & & \\
Number & & & \\
Percent & $\mathbf{1 , 1 3 4 , 9 9 9}$ & 52,484 & $1,187,483$ \\
\hline Hispanic & $\mathbf{9 5 . 5 8}$ & 4.42 & 95.0 \\
Number & & & \\
Percent & 28,674 & $\mathbf{3 3 , 7 7 9}$ & 62,453 \\
\hline Total & 45.91 & $\mathbf{5 4 . 0 9}$ & 5.0 \\
\hline & $1,163,673$ & 86,263 & $\mathbf{1 , 2 4 9 , 9 3 6}$ \\
\hline
\end{tabular}

Source: 2010 Census and Administrative Records. 
Table 4. Comparison of 2010 Census Hot Deck Imputed Race Matched to Administrative Records Race

\begin{tabular}{|c|c|c|c|c|c|c|c|c|}
\hline \multirow[b]{2}{*}{$\begin{array}{c}\text { Census Hot Deck } \\
\text { Race }\end{array}$} & \multicolumn{8}{|c|}{ Administrative Records Race } \\
\hline & $\begin{array}{l}\text { White } \\
\text { Alone }\end{array}$ & $\begin{array}{l}\text { Black } \\
\text { Alone } \\
\end{array}$ & $\begin{array}{c}\text { AIAN } \\
\text { Alone* }\end{array}$ & $\begin{array}{l}\text { Asian } \\
\text { Alone } \\
\end{array}$ & $\begin{array}{c}\text { NHPI } \\
\text { Alone* }\end{array}$ & $\begin{array}{c}\text { SOR } \\
\text { Alone* }\end{array}$ & $\begin{array}{c}\text { Two or } \\
\text { More Races } \\
\end{array}$ & Total \\
\hline $\begin{array}{l}\text { White Alone } \\
\text { Number } \\
\text { Percent } \\
\end{array}$ & $\begin{array}{r}305,485 \\
83.2 \\
\end{array}$ & $\begin{array}{r}22,890 \\
6.2 \\
\end{array}$ & $\begin{array}{r}3,618 \\
1.0 \\
\end{array}$ & $\begin{array}{r}1,894 \\
0.5\end{array}$ & $\begin{array}{r}699 \\
0.2\end{array}$ & $\begin{array}{r}29,843 \\
8.1\end{array}$ & $\begin{array}{r}2,643 \\
0.7\end{array}$ & $\begin{array}{r}367,072 \\
67.2\end{array}$ \\
\hline $\begin{array}{l}\text { Black Alone } \\
\text { Number } \\
\text { Percent } \\
\end{array}$ & $\begin{array}{r}18,854 \\
41.6 \\
\end{array}$ & $\begin{array}{r}23,503 \\
51.9 \\
\end{array}$ & $\begin{array}{r}386 \\
0.9 \\
\end{array}$ & $\begin{array}{r}297 \\
0.7 \\
\end{array}$ & $\begin{array}{r}112 \\
0.3 \\
\end{array}$ & $\begin{array}{r}1,775 \\
3.9 \\
\end{array}$ & $\begin{array}{r}363 \\
0.8 \\
\end{array}$ & $\begin{array}{r}45,290 \\
8.3 \\
\end{array}$ \\
\hline $\begin{array}{l}\text { AIAN Alone* } \\
\text { Number } \\
\text { Percent } \\
\end{array}$ & $\begin{array}{r}1,255 \\
75.9 \\
\end{array}$ & $\begin{array}{r}215 \\
13.0\end{array}$ & $\begin{array}{r}130 \\
7.9\end{array}$ & $\begin{array}{r}15 \\
0.9\end{array}$ & $\begin{array}{r}5 \\
0.3 \\
\end{array}$ & $\begin{array}{r}27 \\
1.6\end{array}$ & $\begin{array}{r}7 \\
0.4\end{array}$ & $\begin{array}{r}1,654 \\
0.3 \\
\end{array}$ \\
\hline $\begin{array}{l}\text { Asian Alone } \\
\text { Number } \\
\text { Percent } \\
\end{array}$ & $\begin{array}{r}8,074 \\
75.5 \\
\end{array}$ & $\begin{array}{r}1,648 \\
15.4 \\
\end{array}$ & $0 . \overline{7}$ & $\begin{array}{r}444 \\
4.2 \\
\end{array}$ & $\begin{array}{r}29 \\
0.3 \\
\end{array}$ & $\begin{array}{r}325 \\
3.0 \\
\end{array}$ & $\begin{array}{r}105 \\
1.0 \\
\end{array}$ & $\begin{array}{r}10,701 \\
2.0 \\
\end{array}$ \\
\hline $\begin{array}{l}\text { NHPI Alone* } \\
\text { Number } \\
\text { Percent } \\
\end{array}$ & $\begin{array}{r}230 \\
68.1 \\
\end{array}$ & $\begin{array}{r}48 \\
14.2 \\
\end{array}$ & $\begin{array}{l}- \\
- \\
\end{array}$ & $\begin{array}{r}15 \\
4.4 \\
\end{array}$ & $\begin{array}{r}19 \\
5.6 \\
\end{array}$ & $\begin{array}{r}14 \\
4.1 \\
\end{array}$ & $2 . \overline{-}$ & $\begin{array}{r}338 \\
0.1 \\
\end{array}$ \\
\hline $\begin{array}{l}\text { SOR Alone* } \\
\text { Number } \\
\text { Percent } \\
\end{array}$ & $\begin{array}{r}77,681 \\
73.2 \\
\end{array}$ & $\begin{array}{r}6,382 \\
6.0 \\
\end{array}$ & $\begin{array}{r}1,635 \\
1.5 \\
\end{array}$ & $\begin{array}{r}459 \\
0.4 \\
\end{array}$ & $\begin{array}{r}407 \\
0.4\end{array}$ & $\begin{array}{r}18,450 \\
17.4 \\
\end{array}$ & $\begin{array}{r}1,153 \\
1.1 \\
\end{array}$ & $\begin{array}{r}106,167 \\
19.4 \\
\end{array}$ \\
\hline $\begin{array}{l}\text { Two or More Races } \\
\text { Number } \\
\text { Percent }\end{array}$ & $\begin{array}{r}10,934 \\
72.4\end{array}$ & $\begin{array}{r}1,696 \\
11.2\end{array}$ & $\begin{array}{r}254 \\
1.7\end{array}$ & $\begin{array}{r}114 \\
0.8\end{array}$ & $\begin{array}{r}86 \\
0.6\end{array}$ & $\begin{array}{r}1,845 \\
12.2\end{array}$ & $\begin{array}{r}181 \\
1.2\end{array}$ & $\begin{array}{r}15,110 \\
2.8\end{array}$ \\
\hline Total & $\begin{array}{r}422,513 \\
77.3\end{array}$ & $\begin{array}{r}56,382 \\
10.3\end{array}$ & $\begin{array}{r}6,102 \\
1.1\end{array}$ & $\begin{array}{r}3,238 \\
0.6\end{array}$ & $\begin{array}{r}1,357 \\
0.3\end{array}$ & $\begin{array}{r}52,279 \\
9.6\end{array}$ & $\begin{array}{r}4,461 \\
0.8\end{array}$ & $\begin{array}{r}546,332 \\
100.0\end{array}$ \\
\hline
\end{tabular}

Source: 2010 Census and Administrative Records.

Note: A dash "-" indicates that the cell is suppressed for dis closure avoidance purposes.

* AIAN is an acronym for American Indian or Alas ka Native, NHPI is an acronymfor Native Hawaiian or Other Pacific Islander, and SOR is an acronymfor Some Other Race. 
Table 5. Logistic Regression Results: Odds Ratios

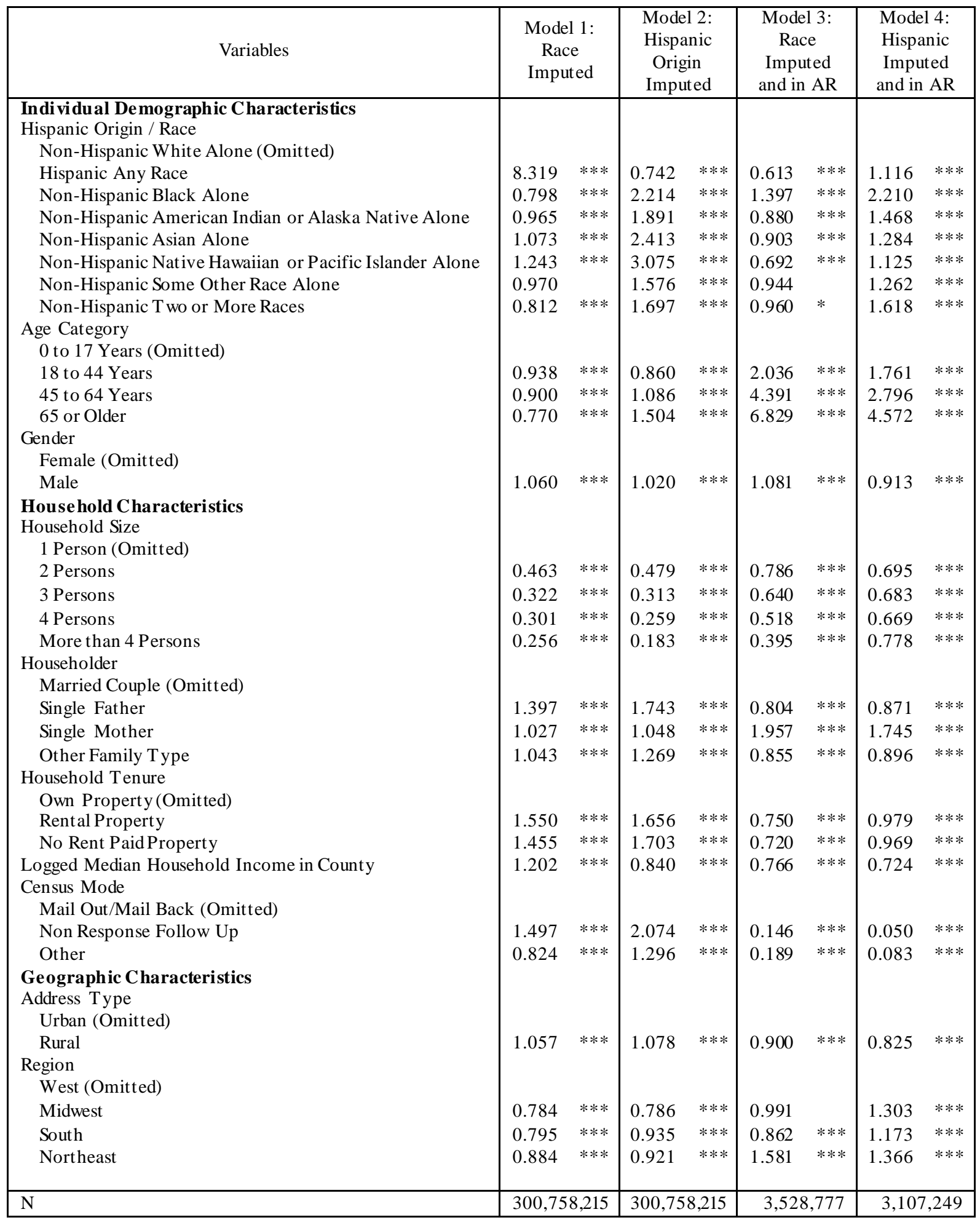

$* \mathrm{p}<.05, * * \mathrm{p}<.01, * * * \mathrm{p}<.001$

Sources: 2010 Census, Administrative Records, and 2006-2010 ACS 5-year data. 